\title{
OCCURRENCE OF GENETIC LINEAGES OF PUCCINIA STRIIFORMIS IN LATVIA
}

\author{
${ }^{*}$ Liga Feodorova-Fedotova ${ }^{1,2}$, Biruta Bankina ${ }^{1}$ \\ ${ }^{1}$ Institute of Soil and Plant Sciences, Latvia University of Life Sciences and Technology, Latvia \\ ${ }^{2}$ Institute of Plant Protection Research, Latvia University of Life Sciences and Technology, Latvia \\ *Corresponding author's email: liga.feodorova-fedotova@llu.lv
}

\begin{abstract}
Puccinia striiformis is a biotrophic pathogen able to cause broad scale epidemics in wheat growing regions. $P$. striiformis is genetically highly variable pathogen. New, aggressive genetic lineages, adapted to warm temperatures have been observed in the last decades worldwide. The study aimed to ascertain the structure of genetic lineages of $P$. striiformis in Latvia. Forty one wheat leaf samples with yellow rust symptoms were collected in 2017-2019. Fenotyping and genotyping methods were used for identification of genetic lineages in Global Rust Reference Center, Denmark. Assessments of leaf diseases on winter wheat differentials - 'Ambition', 'Mariboss', 'Moro', 'Compair', 'Rendezvous', 'Spalding Prolific' and local variety 'Fredis' were made during the research. Five genetic lineages of P. striiformis - PstS4, PstS7, PstS10, PstS13 and PstS14 were found. 56\% from the samples belonged to PstS14, $17.1 \%$ PstS10, 12.2\% PstS4 and PstS7, 2.4\% PstS13. Genetic lineages identified from Latvian wheat samples are found in the biggest cereal growing regions in Europe and are able to cause epidemics on wheat. Genetic lineages of $P$. striiformis from Latvian samples have not been identified before. All differential varieties were infected with P. striiformis in 2017, 'Ambition' and 'Moro' in 2018, no infection was observed on differentials in 2019 despite the presence of $P$. striiformis on winter wheat variety 'Fredis'. The identification of genetic lineages of $P$. striiformis on wheat in Latvia is necessary to continue.
\end{abstract}

Key words: yellow rust, identification, race typing.

\section{Introduction}

Yellow rust caused by $P$. striiformis is one of the main wheat diseases all over the world (Chen, 2005). In susceptible varieties, at early infection yellow rust can provoke $100 \%$ yield losses (Hovmøller et al., 2016; Waqar et al., 2018). Previously, it has been reported that $P$. striiformis is a temperate zone pathogen (Stubbs, 1985) requiring high relative humidity and air temperature from $8{ }^{\circ} \mathrm{C}$ to $12{ }^{\circ} \mathrm{C}$ for successful infection (Dennis, 1987; de VallavieillePope et al., 1995). Since 2000 epidemics of $P$. striiformis have been observed in high-temperature areas (Bayles et al., 2000; Hovmøller et al., 2011; Ali et al., 2014), which could be explained by changes in pathogen's population. New P. striiformis races Kranich, Warrior, Warrior(-), via mutations, somatic and sexual recombinations have appeared (Waqar et al., 2018) and replaced races occurring before 2011 (Ali et al., 2017). New genetic lineages and races are more aggressive, tolerant to warm air temperatures, have shorter latent period, and produce larger number of spores (Milus et al., 2009), thus creating high possibility for epidemics.

An effective method for yellow rust control is the cultivation of wheat varieties containing resistance (Yr) genes. Different types of resistance like seedling resistance and adult plant resistance have been determined. Seedling resistance is provided by single genes and act in all plant growth stages unlike adult plant resistance when resistance performs at postseedling stages (Chen et al., 2014). The duration of host resistance can be influenced by pathogen virulence. Differential sets containing selected wheat varieties with different resistance genes is a widely used tool for pathogen virulence detection (Sørensen, Thach, \& Hovmøller, 2016). Differential sets include 'world differentials', 'European differentials' and some additional cultivars of lines with diverse resistance genes (Chen, 2005) allowing to identify a wide spectrum of genetic lineages and races. Race is defined as a pattern of pathogen and host reactions to inoculation onto host differential sets following gene to gene relationship principle (Hovmøller et al., 2011). Virulence phenotyping is carried out in controlled conditions because of pathogen sensibility of light, air temperature and moisture (VallavieillePope de et al., 1995; Vallavieille-Pope de et al., 2002). For successful inoculation, alive spore samples are necessary (Hovmøller et al., 2011).

Different molecular methods - amplified fragment length polymorphism (AFLP), random amplified polymorphic DNA (RAPD), restriction fragment length polymorphism (RFLP), single nucleotide polymorphism (SNP) markers and simple sequence repeats (SSR) have been used to understand genetic structures of the pathogen (McDonald, 1997). Polymerase chain reaction (PCR) is successfully used for biotrophic fungi detection from infected host tissue (Fraije et al., 2001; Wang et al., 2017). As P. striiformis has genetic stability and genome specificity, genomespecific primers have been developed (Wang et al., 2008). PCR provides rapid and reliable detection of $P$. striiformis before the visual symptoms of the disease have appeared on host leaves. A various number of studies have been performed in relation to the identification of $P$. striiformis genetic lineages with 
molecular methods worldwide (Ali et al., 2010; Wan \& Chen, 2014; Walter et al., 2016).

Yellow rust has been observed in Latvia periodically (Bankina, Jakobija, \& Bimsteine, 2011) and some studies about the possibilities of biological control of yellow rust in field conditions have been started (Feodorova-Fedotova, Bankina, \& Strazdina, 2019). Detailed researches in molecular level and race identification are required.

The objective of this research was to identify the genetic lineages of $P$. striiformis from the wheat leaf samples collected in Latvia 2017-2019.

\section{Materials and Methods}

During the research, wheat leaves with clearly visible yellow rust symptoms were collected in Latvia 2017-2019. In addition, samples were taken from winter wheat differentials. Wheat leaf sample collection procedure was worked out by Global Rust Reference Center (GRRC). From each field 3-5 leaves with visible pustules of $P$. striiformis urediniospores were taken. Green, young leaves without signs of any other plant pathogens were preferred. Each leaf was folded (pustules stayed inside) and put into a paper bag. Leaves were pressed and dried for 24 hours in room temperature. After drying paper bags were put into the paper envelope, sealed with a tape and labelled with a unique ID, and sent to GRRC for race identification. Additional information about the collection date, wheat variety, plant growth stage, which leaf was collected, plant protection products used and field coordinates of each sample were recorded.

Virulence phenotyping performed in GRRC, Denmark was used for genetic lineage identification in all years of research (Hovmøller et al., 2017). Twenty wheat genotypes from world and European differential sets were sown in substrate suitable for cereals. Phenotyping was carried out in controlled conditions with 16 hours day period and temperature $17{ }^{\circ} \mathrm{C}$ during and $12{ }^{\circ} \mathrm{C}$ during the night period (Sørensen et al., 2016). Seedlings were inoculated at the twoleaf stage and placed in dew chamber at $10{ }^{\circ} \mathrm{C}$ for
$24 \mathrm{~h}$ (Wan \& Chen, 2010). Differential responses were evaluated two to three weeks after inoculation (Bayles et al., 2000). For the assessments 0-9 scale was used (Chen et al. 2014). Infection type scores 7-9 indicate wheat susceptibility and pathogen virulence, while infection type scores 0-6 indicate wheat resistance and pathogen avirulence.

For molecular genetic lineage characterization, simple sequence repeats (SSR) were used (Bailey et al., 2015).

Six winter wheat differentials - 'Ambition', 'Mariboss', 'Moro', 'Compair', 'Rendezvous' and 'Spalding Prolific' were sown in the North-Western part of Latvia in 2017-2019. 'Compair' did not overwinter; therefore, the data from this cultivar were not obtained. Differentials were sown in six adjacent rows next to the local susceptible winter wheat variety 'Fredis'. Assessments of wheat leaf diseases were made every week (form $\mathrm{BBCH} 32$ to $\mathrm{BBCH} 75$ ). If P. striiformis were present, samples of wheat leaves were taken and sent to GRRC for race identification.

Resistance to various $P$. striiformis genetic lineages is determined by resistance genes of differentials (Table 1). This information is used for the fenotyping.

\section{Results and Discussion}

Five genetic lineages of P. striiformis - PstS4, PstS7 (Warrior-), PstS10 (Warrior), PstS13 (Triticale2015) and PstS14 were identified during the research (Table 2).

The most common (56\%) genetic lineage in Latvia was PstS14 (Figure 1; Figure 2). This genetic lineage is adapted to high temperatures and has caused epidemics in Morocco (Hovmøller et al., 2018). Data show that the occurrence of PstS14 in Latvia has increased within the years (Table 2). PstS10 (17\%) and PstS7 (12\%) was distributed in 2017 and 2018 respectively, whereas PstS4 (12\%) was common in 2017. PstS13 (3\%) was found only in the first year of research and its occurrence was insignificant.

The composition of $P$. striiformis genetic lineages was diverse within the years of research. In 2017, five

\section{Resistance genes of differentials and the susceptibility to genetic lineages of $P$. striiformis}

\begin{tabular}{|l|l|l|}
\hline \multicolumn{1}{|c|}{ Differentials } & \multicolumn{1}{|c|}{ Resistance genes } & \multicolumn{1}{c|}{ Genetic lineages of P. striiformis able to infect differentials } \\
\hline Ambition & Amb & PstS5, PstS7, PstS8, PstS9 \\
\hline Mariboss & Yr15 & Resistant \\
\hline Moro & Yr10 & PstS2, PstS3, PstS4 \\
\hline Rendezvous & Yr17 & $\begin{array}{l}\text { PstS0, PstS1, PstS5, PstS6, PstS7, PstS8, PstS9, PstS10, PstS11, PstS12, } \\
\text { PstS14 }\end{array}$ \\
\hline Compair & Yr8 & PstS1, PstS2, PstS3, PstS4, PstS8, PstS11, PstS12, PstS13, PstS14 \\
\hline Spaldings Prolific & YrSp, Yr25 & PstS1, PstS2, PstS3, PstS5, PstS7, PstS8, PstS9, PstS10, PstS12, PstS14 \\
\hline
\end{tabular}


Table 2

Identified genetic lineages of Puccinia striiformis in Latvia 2017-2019, \% from collected samples

\begin{tabular}{|c|c|c|c|}
\hline & 2017 & 2018 & 2019 \\
\hline PstS4 & 33 & 0 & 0 \\
\hline PstS7 & 13 & 29 & 5 \\
\hline PstS10 & 40 & 0 & 5 \\
\hline PstS13 & 7 & 0 & 0 \\
\hline PstS14 & 7 & 71 & 90 \\
\hline
\end{tabular}

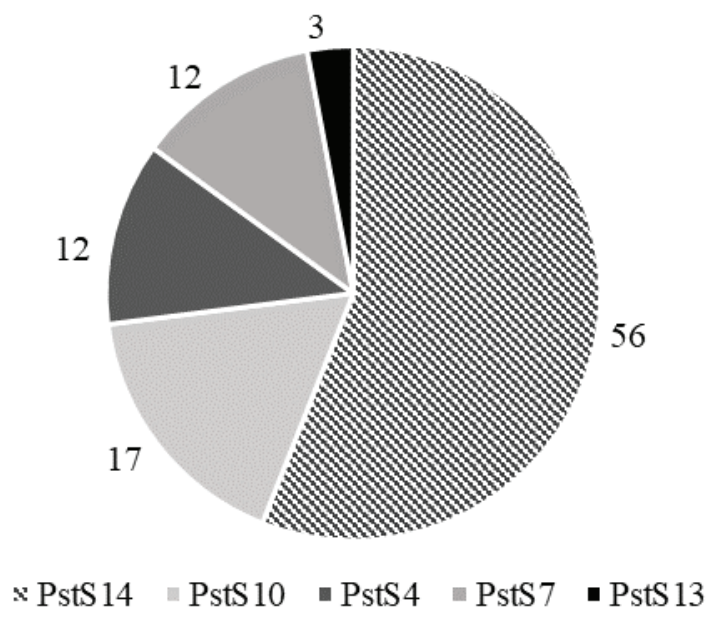

Figure 1. Composition of genetic lineages of $P$. striiformis identified in Latvia, 2017-2019, \%.

different genetic lineages were identified - PstS4, PstS7, PstS10, PstS13 and PstS14. In 2018 PstS7, PstS14 and in 2019 PstS7, PstS10, PstS14 were found (Table 2).

All of the identified genetic lineages are considered aggressive (Hovmøller et al., 2018) and may initiate new epidemics (Brown \& Hovmøller, 2002). More attention to $P$. striiformis has been paid after 2009 due to the emergence of new races causing economically significant epidemics. PstS4 were common on triticale in Scandinavia 2009-2011, whereas PstS7 and PstS10 were ones of the main genetic lineages on wheat in Europe since 2011 (Ali et al., 2017) and have replaced genetic lineages occurred before. PstS13 dominates in South America (Argentina, Chile) and have caused epidemics on wheat and triticale in 2018. PstS14 the first time was detected in 2016 from samples collected in Morocco (Hovmøller et al., 2018).

In Latvia, genetic lineage identification of $P$. striiformis has not been performed before. The obtained data confirm the presence of aggressive genetic lineages of $P$. striiformis in Latvia. Information of virulence phenotype of identified genetic lineages allows choosing resistant wheat varieties for cultivation.

Various infection of $P$. striiformis was observed in field trials on differentials during the research. Winter wheat variety 'Fredis' was infected in all years, PstS7, PstS10 and PstS14 were identified from the samples.

In conformity with resistance genes, assessed differentials are susceptible to PstS0, PstS1, PstS2, PstS3, PstS4, PstS5, PstS6, PstS7, PstS8, PstS9, PstS10, PstS11, PstS12, PstS13 and PstS14 genetic lineages. All differentials were infected with P. striiformis in 2017. A year later only 'Ambition' and 'Moro' were infected but in 2019 no symptoms of yellow rust were observed on differentials (Table 3). According to the resistance genes and identified genetic lineages of P. striiformis, 'Ambition' should be infected in 2019. The low infection level and irregular distribution of yellow rust could explain the absence of $P$. striiformis on differentials in 2019. Although winter wheat 'Mariboss' should be resistant to PstS4, PstS7, PstS10, PstS13 and PstS14, infection on this variety was observed in 2017. A new, unidentified genetic lineages could be present in Latvia. Winter wheat variety 'Moro' was infected with yellow rust in 2018 (Table 3), when PstS14 genetic lineage was identified.

The obtained data, although contradictory, provide first insight in genetic diversity and virulence of $P$. striiformis in Latvia. The research on genetic lineage typing of $P$. striiformis needs to be continued. 


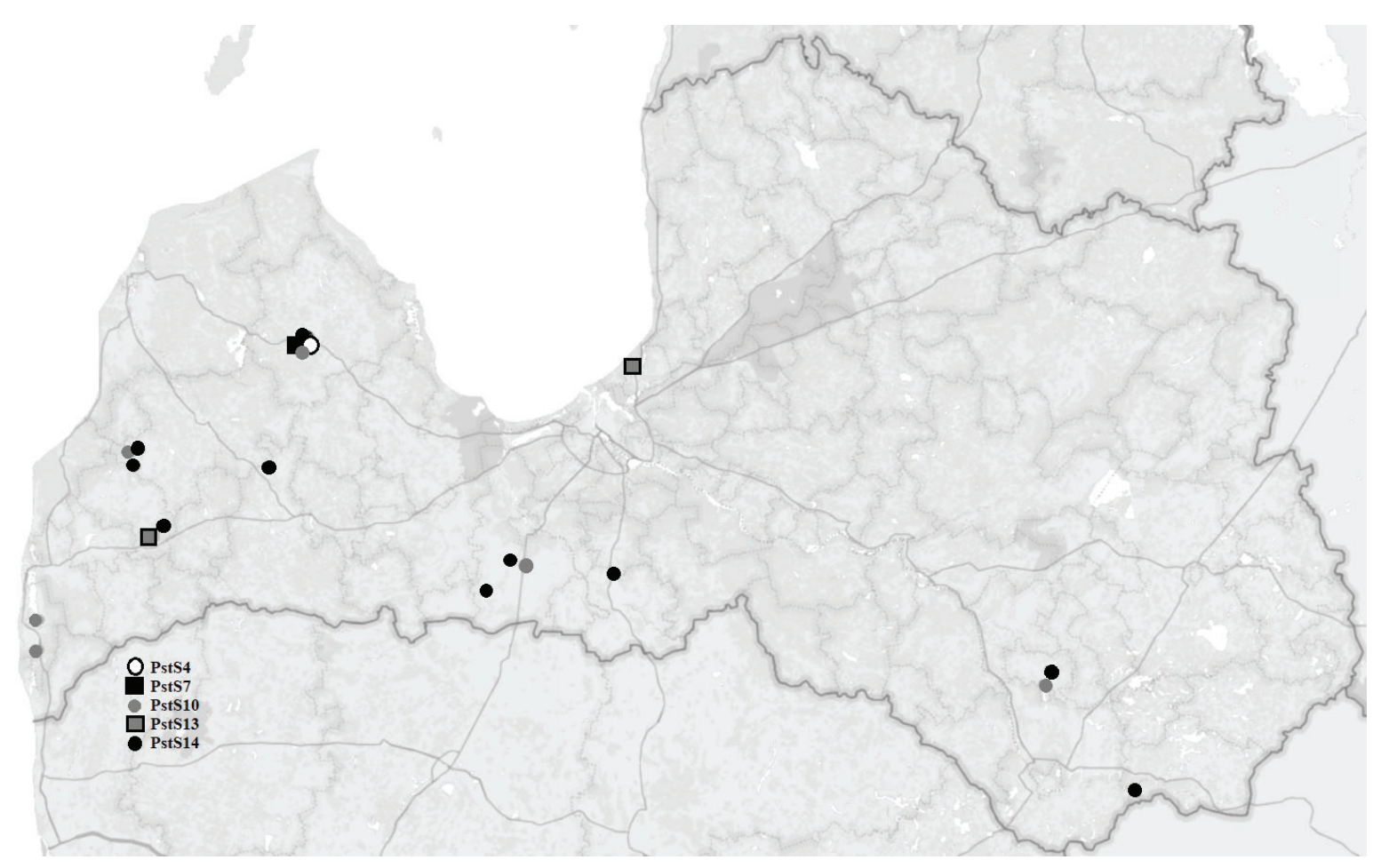

Figure 2. Identified genetic lineages and spatial distribution of P. striiformis in Latvia 2017-2019.

Infection of winter wheat differentials with yellow rust in field trials, 2017-2019

Table 3

\begin{tabular}{|l|c|c|c|c|c|c|}
\hline & \multicolumn{2}{|c|}{2017} & \multicolumn{2}{c|}{2018} & \multicolumn{2}{c|}{2019} \\
\cline { 2 - 7 } & $\begin{array}{c}\text { Should be } \\
\text { infected in } \\
\text { accordance } \\
\text { of detected } \\
\text { Winter wheat differential }\end{array}$ & Infection & $\begin{array}{c}\text { Should be } \\
\text { infected in } \\
\text { accordance } \\
\text { of detected } \\
\text { races }\end{array}$ & Infection & $\begin{array}{c}\text { Should be } \\
\text { infected in } \\
\text { accordance } \\
\text { of detected } \\
\text { races }\end{array}$ & Infection \\
\hline Ambition & $\times$ & $\times$ & $\times$ & $\times$ & $\times$ & - \\
\hline Mariboss & - & $\times$ & - & - & - & - \\
\hline Moro & $\times$ & $\times$ & - & $\times$ & - & - \\
\hline Rendezvous & $\times$ & $\times$ & $\times$ & - & $\times$ & - \\
\hline Spalding Prolific & $\times$ & $\times$ & $\times$ & - & $\times$ & - \\
\hline
\end{tabular}

\section{Conclusions}

Genetic lineages that have caused epidemics in the biggest wheat growing regions are identified in Latvia.

Identified genetic lineages-PstS4, PstS7 (Warrior-), PstS10 (Warrior), PstS13 (Triticale2015) and PstS14 cover a wide spectrum of virulence phenotype.

\section{Acknowledgements}

The research was financed by the Latvia Ministry of Agriculture project 'Distribution of yellow rust disease causal agent Puccinia striiformis, Wes. races in Latvia and measures to minimize the damage in wheat fields' and Latvia University of Life sciences and Technologies project 'Identification of the races of yellow rust causal agent Puccinia striiformis and evaluation of wheat varieties resistance against yellow rust in the laboratory conditions'.

Authors are grateful to Global Rust Reference Center for race identification.

\section{References}

Ali, M., Ji, W.Q., Hu, Y.G., Baloch, G.M., Zhong, H., \& Wang, C.Y. (2010). Molecular implications from Ssr markers for stripe rust (Puccinia striiformis f. sp. tritici) resistance gene in bread wheat line N95175. Pak. J. Bot., 42(1), 383-390. 
Ali, S., Gladieux, P., Leconte, M., Gautier, A., Justesen, A.F., Hovmøller, M.S., ... de Vallavieille-Pope, C. (2014). Origin, migration routes and worldwide population genetic structure of the wheat yellow rust pathogen Puccinia striiformis f.sp. tritici. PLoS Pathog, 10(1), e1003903. DOI: 10.1371/journal. ppat.1003903.

Ali, S., Rodriguez-Algaba, J., Thach, T., Sørensen, C.K., Hansen, J.G., Lassen, P., ... Hovmøller, M.S. (2017). Yellow rust epidemics worldwide were caused by pathogen races from divergent genetic lineages. Front. Plant Sci., 8, 1557. DOI: 10.3389/fpls.2017.01057.

Bankina, B., Jakobija, I., \& Bimsteine, G. (2011). Peculiarities of wheat leaf disease distribution in Latvia. Acta Biol. Univ. Daugavp., 11(1), 47-54. DOI: 10.5586/aa.2005.059.

Bailey, J., Karaoglu, H., Wellings, C.R., \& Park, R.F. (2015). PCR-based simple sequence repeat markers for diagnostic identification of major clonal lineages of Puccinia striiformis f. sp. tritici and related stripe rust pathogens in Australia. Australasian Plant Pathol., 44, 97-103. DOI: 10.1007/s/13313-014-0326-3.

Bayles, R., Flath, K., Hovmøller, M., \& de Vallavieille-Pope, C. (2000). Breakdown of the Yr17 resistance to yellow rust of wheat in northern Europe. Agronomie, 20, 805-811. DOI: 10.1051/agro:2000176.

Brown, J.K.M., \& Hovmøller, M.S. (2002). Aerial dispersal of fungi on the global and continental scales and its consequences for plant disease. Science, 297, 537-541.

Chen, W., Wellings, C., Chen, X., Kang, Z., \& Liu, T. (2014). Wheat stripe (yellow) rust caused by Puccinia striiformis f. sp. tritici. Molecular Plant Pathology, 15(5), 433-446. DOI: 10.1111/mpp.12116.

Chen, X.M. (2005). Review / Synthèse Epidemiology and control of stripe rust [Puccinia striiformis f. sp. tritici] on wheat. Canadian Journal of Botany, 27, 314-337. DOI: 10.1071/ar07045.

Dennis, J.I. (1987). Temperature and wet-period conditions for infection by Puccinia striiformis f. sp. tritici race 104e137a+. Trans. Br. Mycol., 88(1), 119-121. DOI: 10.1007/BF02879166.

Feodorova-Fedotova, L., Bankina, B., \& Strazdina, V. (2019). Possibilities for the biological control of yellow rust (Puccinia striiformis) in winter wheat in Latvia in 2017-2018. Agronomy Research, 17(3), 716-724. DOI: 10.15159/AR.19.137.

Fraije, B.A., Lovell, D.J., Coelho, J.M., Baldwin, S., \& Hollomon, D.W. (2001). PCR-based assays to assess wheat varietal resistance to blotch (Septoria tritici and Stagonospora nodorum) and rust (Puccinia striiformis and Puccinia recondita) diseases. European Journal of Plant Pathology, 107, 905-917. DOI: 10.1023/a:1013119206261.

Hovmøller, M.S., Sørensen, C.K., Walter, S., \& Justesen, A.F. (2011). Diversity of Puccinia striiformis on cereals and grasses. Annual Review of Phytopathology, 49(1), 197-217. DOI: 10.1146/annurevphyto-072910-095230.

Hovmøller, M.S., Walter, S., Bayles, R.A., Hubbard, A., Flath, K., Sommerfeldt, N., .... de Vallavieille-Pope, C. (2016). Replacement of the European wheat yellow rust population by new races from the centre of diversity in the near-Himalayan region. Plant Pathology, 65(3), 402-411. DOI: 10.1111/ppa.12433.

Hovmøller, M.S., Rodriguez-Algaba, J., Thach, T., \& Sørensen, C.K. (2017). Race typing of Puccinia striiformis on wheat. Wheat Rust Diseases, 1659, 29-40. DOI: 10.1007/978-1-4939-7249-4.

Hovmøller, M.S., Rodriguez-Algaba, J., Thach, T., Justesen, A.F., \& Hansen, J.G. (2018). Report for yellow rust race analysis 2018. GRRC, Aarhus University, Denmark, 1-8. Retrieved February 16, 2020, from https://agro.au.dk/fileadmin/www.grcc.au.dk/International_Services/Pathotype_YR_results/Summary_ of_Puccinia_striiformis_molecular_genotyping_2018.pdf.

McDonald, B.A. (1997). The population genetics of fungi: tools and techniques. Phytopathology, 87, 448-453.

Milus, E.A., Kristensen, K., \& Hovmøller, M.S. (2009). Evidence for increased aggressiveness in a recent widespread strain of Puccinia striiformis f. sp. tritici causing stripe rust of wheat. Phytopathology, 99(1), 89-94. DOI: 10.1094/PHYTO-99-1-0089.

Stubbs, R.W. (1985). The cereal rusts. Orlando, Florida: Academic Press.

Sørensen, C.K., Thach, T., \& Hovmøller, M.S. (2016). Evaluation of spray and point inoculation methods for the phenotyping of Puccinia striiformis on wheat. Plant Dis., 100, 1064-1070. DOI: 10.1094/PDIS-1215-1477-RE.

Vallavieille-Pope de, C., Huber, L., Leconte, M., \& Goyeau, H. (1995). Comparative effects of temperature and interrupted wet periods on germination, penetration, and infection of Puccinia recondita f. sp. tritici and P. striiformis on wheat seedlings. Phytopathology, 85(4), 409-415. DOI: 10.1094/ Phyto-85-409.

Vallavieille-Pope de, C., Huber, L., Leconte, M., \& Bethenod, O. (2002). Preinoculation effects of light quantity on infection efficiency of Puccinia striiformis and P. triticina on wheat seedlings. Phytopathology, 92(12), 1308-1314. DOI: 10.1094/PHYTO.2002.92.12.1308. 
Walter, S., Ali, S., Kemen, E., Nazari, K., Bahri, B.A., Enjalbert, J., ... Justesen, A.F. (2016). Molecular markers for tracking the origin and worldwide distribution of invasive strains of Puccinia striiformis. Ecology and Evolution, 6(9), 2790-2804. DOI: 10.1002/ece3.2069.

Wan, A.M., \& Chen, X.M. (2014). Virulence characterization of Puccinia striiformis f. sp. tritici using a new set of $Y r$ single-gene line differentials in the United States in 2010. Plant Dis., 98(11), 1534-1542. DOI: 10.1094/PDIS-01-14-0071-RE.

Wang, X.J., Zheng, WM., Buchenauer, H., Zhao, J., Han, Q.M., Huang, L.L., \& Kang, Z.S. (2008). The development of a PCR-based method for detecting Puccinia stiiformis latent infections in wheat leaves. European Journal of Plant Pathology, 120, 241-247. DOI: 10.1007/s10658-007-9212-y.

Wang, S., Chu, B., Liu, Q., Luo, Y., \& Ma, Z. (2017). Development of a sequence-characterized amplified region marker using inter-simple sequence repeats for detection of Puccinia striiformis f. sp. tritici. Journal of Phytopathology, 165(7-8), 442-447. DOI: 10.1111/jph.12578.

Waqar, A., Khattak, S.H., Begum, S., Rehman, T., Rabia, Shehzad, A., ... Ali, G.M. (2018). Stripe rust: A review of the disease, Yr genes and its molecular markers. Sarhad Journal of Agriculture, 34(1), 188-201. DOI: 10.17582/journal.sja/2018/34.1.188.201. 